\title{
Cooperative Strategic Entrepreneurship: A Case Study from Indonesia
}

\author{
Mochamad Heru Riza Chakim*, Erna Maulina, Margo Purnomo, Anang Muftiadi and \\ Achsanul Qosasi
}

\author{
Department of Social and Political Science, Jl. Bukit Dago Utara No.25, Dago, Kecamatan Coblong, Kota \\ Bandung, Jawa Barat 40135, Indonesia
}

\begin{abstract}
This article offers an in-depth case study of the relevance of dairy cow milk cooperatives in Indonesia that align with the concept of strategic entrepreneurship in social benefit practices. An advocacy lens based on the strategic entrepreneurship model is used by making comparisons of the constructs that form strategic entrepreneurship to bridge a practical understanding of cooperatives with local cultural backgrounds. Descriptive analysis is used to report interrelated themes in the case study of cooperative organizations and finally interpretation.

An interesting finding is based on the research results, that is, the wealth creation of an organization is not the final model variable, but a social benefit variable, which then becomes a cycle of environmental resources. Cooperatives realize that personal benefits are not a sub-variable of constructing goals. This research describes the dynamics of the opening of the concept of strategic entrepreneurship in cooperative companies that consider new social risks and benefits.
\end{abstract}

Keywords: Strategic entrepreneurship, cooperative, social enterprises, Indonesia.

\section{INTRODUCTION}

Top management strategically has the discretion to determine the direction of the co-operative. Cooperatives as organizations have myths and are dysfunctional (Meyer \& Rowan, 1977), if influenced by the social environment. Top management, as entrepreneurs take entrepreneurial action so that the organization has entrepreneurial values. Co-operatives with an entrepreneurial attitude are mentioned in the book Entrepreneurship Co-operative en Belgique: théories et pratiques, written by Gijselinckx and Van Opstal in 2008. The proposal mention co-operative entrepreneurship as 'a way to do business that is practiced within voluntarily formed economic organizations to obtain common benefits that would be impossible to achieve individually by the members who form the organization' (Diaz-Foncea \& Marcuello, 2013). More emphasis must be placed on the element of entrepreneurship by including behavioural perspectives that connect entrepreneurs with the creation of new organizations.

The previous conceptual assumption states that creating organizational wealth (Welter et al., 2016), benefits socially (Tocher et al., 2015), organizationally and individually. This article attempt to find an answer to how SE is explored in the field of cooperatives? Further and deeper to create wealth for the

*Address correspondence to this author at the Faculty of Social and Political Science, Jl. Bukit Dago Utara No.25, Dago, Kecamatan Coblong, Kota Bandung, Jawa Barat 40135, Indonesia; E-mail: heruriza11@gmail.com organization, members, and society and how cooperative administrators describe SE implementation? in Indonesia.

\section{THEORETICAL BACKGROUND}

\subsection{Cooperative}

A cooperative is the concept of an organization where individuals work together and can help explain how humans defend organizations, markets, and religions (Tremblay et al., 2019). Usually, a cooperative is composed of a personal network of volunteers who own or control an enterprise that distributes benefits based on use or ownership, and ownership is roughly equal among members. Income is composed of, for example, a portion of surplus or profit, improved working conditions and income, lower prices, higher product quality, product types and varieties, so as to better meet the preferences of members and obtain better credit opportunities. The members control the cooperative based on one member's vote and guarantee a platform for exercising voice. Members invest in cooperatives and therefore have financial interests in the organization. Unlike typical private enterprises, in cooperative finance, cooperative financial risks are narrowly distributed among users or workers, while in private enterprises, ownership and financial risks do not have to fall on the shoulders of users or workers. In some jurisdictions, the risks to cooperative owners are limited by the limited liability protection provided by law (Anheier et al., 2010). 
The cooperative movement is strictly defined and closely related to the democratic governance of the members. Cooperatives are not just a group of individuals who cooperate in specific economic activities. This kind of cooperation can be carried out under compulsory forms of governance, from serfdom to slavery to the Communist Party of China, the Soviet Union and the state-sponsored collectives of Cuba. Part-time labour in a democratic society also requires cooperation between economic participants. However, even if cooperatives proceed relatively freely, they need more than pure cooperation. The modern cooperative movement aspires to first clearly and coherently articulate a set of principles by members of the Rochdale Consumer Cooperative (Corina, 1994), founded by 28 weavers in Rochdale, England, with relatively limited work and consumer rights. Consumer cooperatives were not subject to legal sanctions in England until 1852. The original "Rochdale Principles" (Anheier et al., 2010; Birchall, 1997; MacPherson, 2012) that defined cooperative organizations are :

\section{Democratic control (one member, one vote)}

2. Open membership

3. Limited interest on capital

4. Distribution of surplus in proportion to a member's contribution to the society

5. Cash trading only (no use of credit)

6. Providing for the education of members in cooperative principles

7. Political and religious neutrality

For the International Cooperative Union (ICA), which is the official governing body of cooperatives, four of the following Rochdale principles are essential to member organisations' governance. The first is the principle of open membership. The second is democratic control. The third is distributing the surplus to members in proportion to transactions and limited rights and interests in the capital. Among the principles used in ICA, the other three principles are considered important and necessary for ICA membership. These three principles are political and religious neutrality, only cash transactions and promotion of education. The principles updated in 2018 and used in 2021 are a concern for community. Cooperatives work for the community's sustainable development through policies approved by their members (The International Cooperative Alliance, 2018).

\subsection{Strategic Entrepreneurship}

Strategic entrepreneurship is an entrepreneurial behaviour with a strategic perspective. Strategic entrepreneurship is a combination of entrepreneurial perspectives (that is, the behaviour of seeking opportunities) and strategic perspectives (that is, seeking advantages) in formulating and taking actions aimed at creating wealth Methods. (Ireland et al., 2003)

Early attempts to integrate entrepreneurship and strategic management focused on these two disciplines (Covin \& Miles, 1999). Innovation, internationalization, organizational learning, alliances and networks, top management teams and governance, and growth are research areas in early SE research (M. A. Hitt et al., 2001; M. A. Hitt \& Duane, 2002; Ireland, 2001).

Research conducted by (M. A. Hitt et al., 2001; M. A. Hitt \& Duane, 2002) and (Ireland, 2001) integrates and summarizes the basic principles of entrepreneurship and strategic management. Their main objective is to identify theoretically rich research questions to enhance understanding of wealth creation in new ventures and established companies. Overall, this work suggests that both entrepreneurship and strategic management are concerned with how companies can create change (adaptability or initiative) by taking advantage of opportunities created by the external environment's uncertainty (M. A. Hitt et al., 2001; Ireland, 2001).

Previous researchers proposed a set of potential and unique dimensions of strategic entrepreneurship, including its key structures and their respective subcomponents and actions. This is a sequential model to a large extent, where integration depends on the application of various theoretical foundations, borrowed from various literary sources, and partly depends on the proposed theoretical connections, which include seeking opportunities and seeking profit. Although it includes dimensions and processes at the individual level, it is, above all, a strategic entrepreneurial model at the enterprise level. In essence, companies characterized by human resource entrepreneurship and managing resources strategically are also expected to demonstrate the creativity and innovation capabilities needed to create wealth Ireland et al. (2003)

Kyrgidou \& Hughes (2010) interpreted the (Ireland et al., 2003) model as a linear or stage model, agreeing with its basic logic, but proposed a series of 


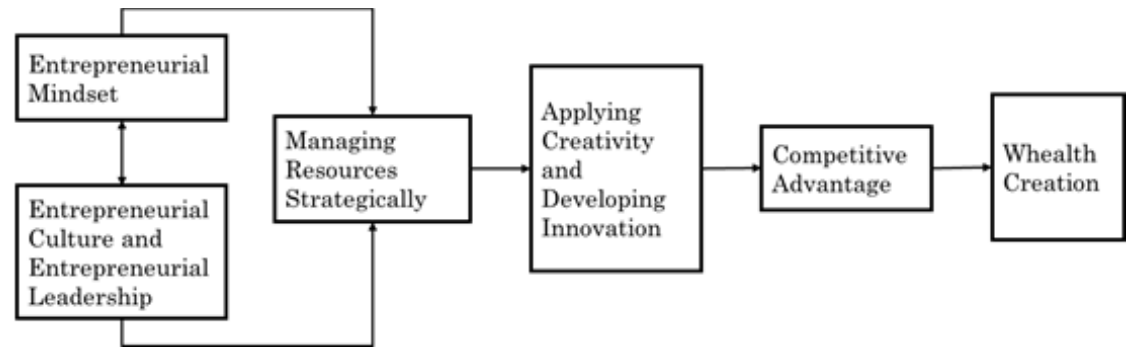

Figure 1: Model of Strategic entrepreneurship (Ireland et al., 2003).

extensions. They particularly recommend introducing feedback loops and learning mechanisms, especially in the form of dynamic capabilities for exploration and development purposes, and an expanded collection of internal organizational factors that affect the company's search for opportunities and advantages. The author does not emphasize the integration or simultaneous application of opportunities and advantage-seeking activities but instead emphasizes the company's ability to shift time between two conflicting operating models. Luke et al. (2011)) also shared their emphasis on strategic entrepreneurial motivation, and they emphasized the importance of continuous management to achieve potential financial benefits. The input process output model outlined by M. Hitt et al. (2011) retains and reorganizes several core elements of Ireland et al. (2003).

Likewise, Ireland \& Webb (2009) consider the transition between exploration and development activities as an essential part of strategic entrepreneurship (Lumpkin et al., 2011). This leads to the introduction of new elements, such as environmental factors. Their model further expands the potential yield portfolio to include wealth creation and other benefits at the personal, organizational, and social levels. The linear model shows that among the input factors, including environment, organization, and individual resources at all levels, the impact of seeking opportunities and seeking profit at the same time is very prominent.

In essence, it is a linear model in which, Various input factors, including resources at all levels of the environment, organization, and individuals, are particularly affected by seeking opportunities and seeking advantages. Summarized by Kraus et al. (2011) the main concepts and variables of the previous model. They used a configuration method to explore the so-called relationship between the key areas of strategic entrepreneurship (at the core of a set of strategic entrepreneurship literature articles). Although they emphasize the complexity of key concepts or interrelationships between domains, their conceptual models show that the expansion of previous methods includes a set of strategy types and clarifies the relationship between resources and general capabilities.

Schindehutte \& Morris (2009) used complexity science as the starting point for the early model and conceptualization of strategic entrepreneurship and proposed another paradigm that can better describe and capture the interaction between the main components of strategic entrepreneurship. Connection and feedback loops (within the concept of opportunity

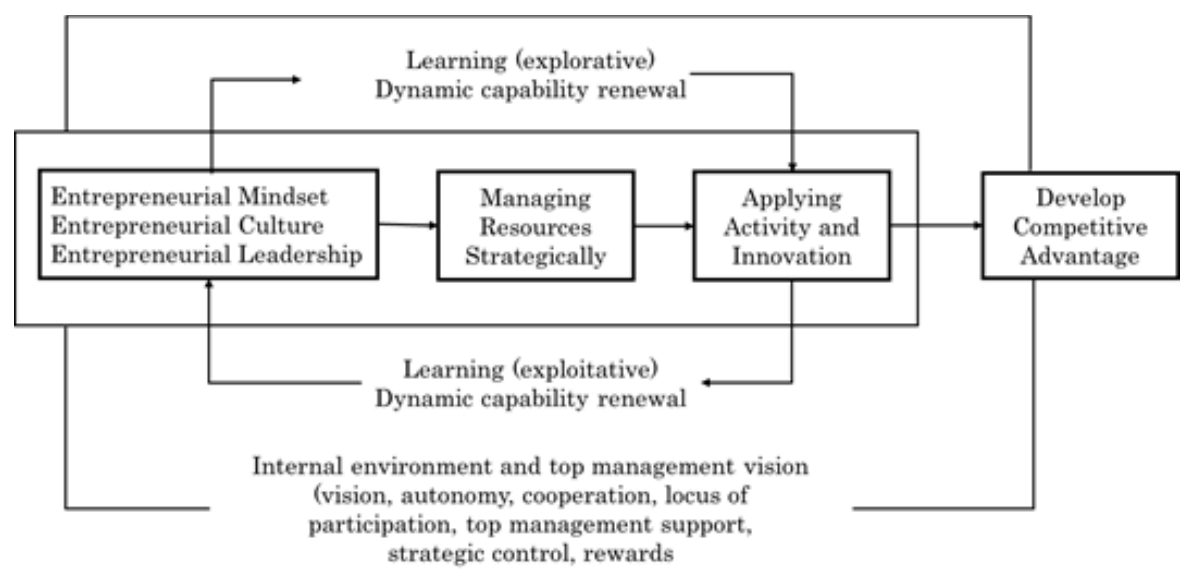

Figure 2: Improved and Practical model of Strategic entrepreneurship (Kyrgidou \& Hughes, 2010a). 


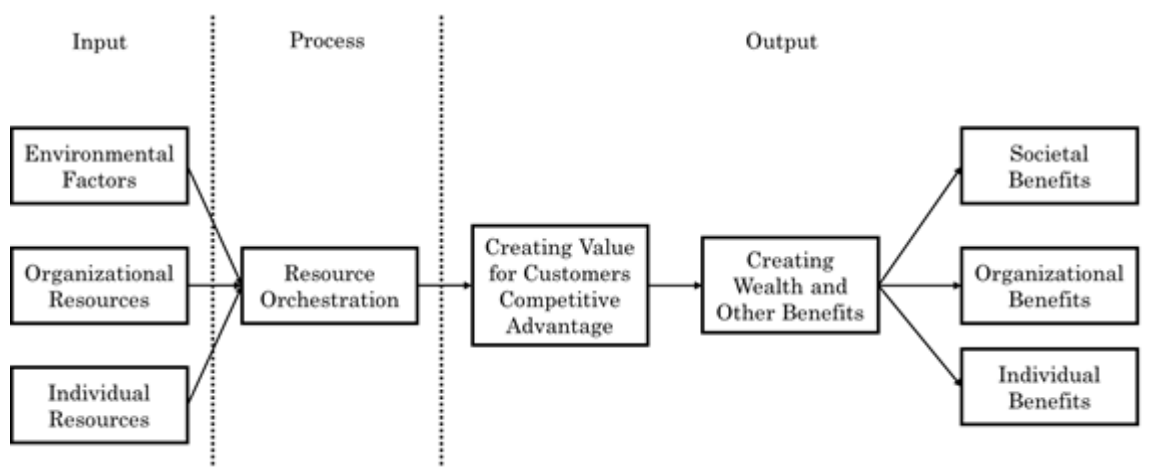

Figure 3: Input-process-output model of SE (M. Hitt et al., 2011) model.

space), combined with the multi-level analysis evident in the early strategic entrepreneur model (Ireland et al., 2003; Kyrgidou \& Hughes, 2010b).

The implicit model captures the "content, reason, method, person, place and time of strategic entrepreneurship," implying the intricate interaction between components or elements, the results of which are still largely unpredictable. Therefore, the author pays more attention to outcomes such as novelty and pace of change rather than just creating wealth (Morici \& Zander, 2020).

\section{METHOD}

In this case study, the object of research is the Setiakawan Cooperative in Pasuruan City, East Java Province, Indonesia. Data from this case study is taken over a certain period of time by collecting detailed information on an ongoing basis through structured procedures (Creswell, 2013).

The data was collected through face-to-face interviews, focus group discussions, and observations. Interviews using a list of questions that fit the SE model of the study were recorded, then stored. The recorded speech is saved as audio. The Focus Group Discussion was conducted in a room with participants, namely the founder of the cooperative, the management of the cooperative, and members of the cooperative moderated by the researcher. The lead researcher participated in the group by inviting representatives of Sucofindo, cooperatives, and other elements of society as participants in the activity. Observations were made by visiting the location of the cooperative business unit for dairy cow milk production in the community, milk processing, educational tourism services, and souvenirs.

Measurement of data information was carried out using one-shot experimental design by making a list of questions related to the SE construct based on the variables proposed by Ireland (2003), then conducting interviews with cooperative managers, cooperative members, and related community elements. Data triangulation at the FGD meeting was conducted to measure the validation of the influence of strategic entrepreneurship on the interviewed organization. Written data and recorded interviews were then documented for analysis. Data analysis was carried out by listening to the data coding again from recording and documenting written data, then analyzed and sorted according to the theme and description of the SE construct according to Hitt (2011). Descriptive analysis is used to report interrelated themes in the case study of cooperative organizations and finally interpretation.

\section{DISCUSSION}

\subsection{Environmental Factor, Organizational Factor, Individual Resources}

How co-operatives capture the benefits of uncertainty. Uncertainty is a phenomenon of perception that stems from the inability to assign probabilities to future events, mainly due to a lack of information about causal relationships (Welter et al., 2016). The council of co-operatives expresses recognition of business opportunities. Consider government policy support is evidenced by holding hearings with the ministry of agriculture and capital support from PT Sucofindo through corporate social responsibility funds (CSR).

Risk and ambiguity are part of uncertainty. The cooperative's view of the statement is conveyed through an explanation of the main factors that underlie the cooperative direction and policy, namely how we serve members as well as possible. Second, there is a partnership, partnership with state-owned enterprises, banking, and, most importantly, with universities. In addition to members focusing on dairy cows' core 
business, it hoped that cooperation with the university would open the way for members to find other business commodities from cow milk such as milk chips or milk candy.

The role of universities in cooperation with cooperatives is training 210 children of cattle ranchers to become good breeders. So the co-operative does not lose cattle farmers in the future. So there is no urban behaviour, unemployment, and switch to other businesses. Besides that, concerning government policy, the co-operative is preparing itself to make dairy cattle business commodity as a regional tourism activity. International cooperation is also carried out with dairy companies from Denmark to add value to these dairy products. Improving the quality of milk is expected to leverage the opening of a more extensive market share through organic milk.

The greatest strength of the cooperative organization is at the level of group awareness. Where the fundamental values that are always instilled for members are the value of fulfilling services to their members well. The co-operative has the support of its members and 640 more madrasa teachers who met their needs every month. It helps the family welfare of the madrasa teachers, although not much. The form of assistance in the form of holiday allowances, worship equipment such as teacher uniforms. Another assistance is done by providing support to villages in the form of development funds each year based on tonnage contributions each month.

The most significant attention is directed at the orphanage foundation. Co-operatives meet the monthly foundation needs. By involving employees, administrators, and orphans, the commemoration of the birth of the great prophet Muhammad was carried out by proselytizing to remind self-awareness of the presence of Allah almighty in every work activity. It is hoped that these activities will maintain and increase loyalty to the co-operative organization. Most members of the co-operative do not care where someone comes from. The most important thing is to want to obey the rules of the group and work hard.

Five principles form the basis of co-operative organization activities. First is intention. Every stakeholder must have good intentions. Whether it is the management, supervisor, members are required to have good intentions. There is no strange intention, let alone have a hidden agenda. The second principle, all existing components are involved in activities. Each component is required to contribute and work together in carrying out activities. Third, cast a spell on every activity through the core of the dairy business. The fourth principle is a partnership. This partnership can stimulate its members to remain productive in their activities. The final principle is solidarity and candour. It is expected that with solidarity and candour, the expected results would be a blessing.

The characteristics of leadership styles in cooperatives are very influential in organizational operations. When a leader is capable of an entrepreneurial capability to manage the organisation's strategic resources, dexterity, creativity, and skills are no longer in doubt. Leaders who always explore each of their members' best potentials openly protect the innovations threatening the current business model. How leaders conceptualize their business and evaluate strategic resource management decisions by communicating the value of opportunity for the entire organisation's goals.

The loyal friend's co-operatives annually hold annual member meetings by listening down, seeking input, seeking criticism, and giving advice from members from village to village. Thirteen villages were visited with a $99 \%$ attendance rate at the meeting. The high level of attendance is due to enthusiasm, pleasure, and pride in his co-operative, with a total membership of 10 thousand members with 6 thousand five hundred active members of milk deposit. The rest of the members whose cows are dry or have a calf, so they do not participate in the deposit. The second phase of the annual meeting is carried out by summoning the representatives of the members and their assistants in each village to make a future work program. There are two groups in the meeting, business groups, and organizational groups, which will be formulated in the organization's plenary session.

The leader of this co-operative was ridden by a person named Haji Kusnan. However, as a leader, he does not want to stand out. Every morning the meeting is led by him with an agenda to explore opinions, input, and thoughts of what will be done and resolved today. There is no standard style top-down or down-top in a leadership capacity at the chairman level, but rather a teamwork style. The chairman, who has no innovation, thought, and initiative, will be seen and eliminated in the next chairman's election. Therefore the leadership of the chairperson is the mandate of the members responsible before God. The religious approach is instilled in members and administrators in organizing. 
This approach gives rise to a more substantial adhesive value above all.

To strengthen this approach, each chairperson has a foundation that moves to think about dairy farmers, the future of the younger generation of cattle farmers, formal and religious education for children, care for orphans, and widows so that emotional attachment to citizens arises. When something happens to the cooperative, residents can directly face and ask informally so that the level of concern members is very high of this organization. There are seven chairmen of the organization, and 6 of them have foundations.

\subsection{Strategically Orchestrating Resources}

Financial resources are managed by sharing a percentage of $93 \%$ of the profits returned to the cooperative members, 6 per cent distributed to the operation management, 1 per cent to teachers of the Koran recitation, distributed in the form of holy books, worship equipment, and compensation for those in need. 640 madrasah teachers are managed each month and are given compensation by the cooperative. The cooperative develops a competitive advantage in the form of values to achieve collective wealth by providing knowledge about religion to children so that they are ready to continue the dairy farming business in the future. Madrasah teachers are the key to overall cooperative resource management. In addition to providing knowledge to children, madrasah teachers also provide knowledge to administrators or employees by sharing experiences and sharing tacit skills of knowledge to be better in their capacity.

\subsection{Societal Benefit and Organizational Benefit}

Further theoretical elaboration on the reasons for social enterprises' diversity - and their loci developed by exposing the contradictions in social enterprise's various definitions. The concept of social rationality is used to offer new perspectives that accommodate the diversity found in the sector and the role of cooperatives in building benefits for the wider community.

The discourse on developing social capital reveals that cooperatives carry out non-profit activities and more profitable activities. The strength of the social benefits emphasized on the organization attests to the increase in dairy cows' milk production from year to year. Based on observational data, the production of cooperatives per year has increased by 2 tons with 1000 cooperative members.

The perspective of economic improvement for the wider community, expressed in the seventh principle of ICA concern for community is carried out well in cooperatives. Without ignoring the problems of having different opinions in individual groups' interests, cooperatives have succeeded in promoting collective interests for the organization.

It is recognized that not all cooperatives have a "more than profit orientation" mentality. This mentality began in 1911 by prioritizing religious activities as the foundation of personal and community life. This mentality has succeeded in passing the cycle of the world economic crisis simultaneously. Leaders and managers of cooperatives try from time to time to

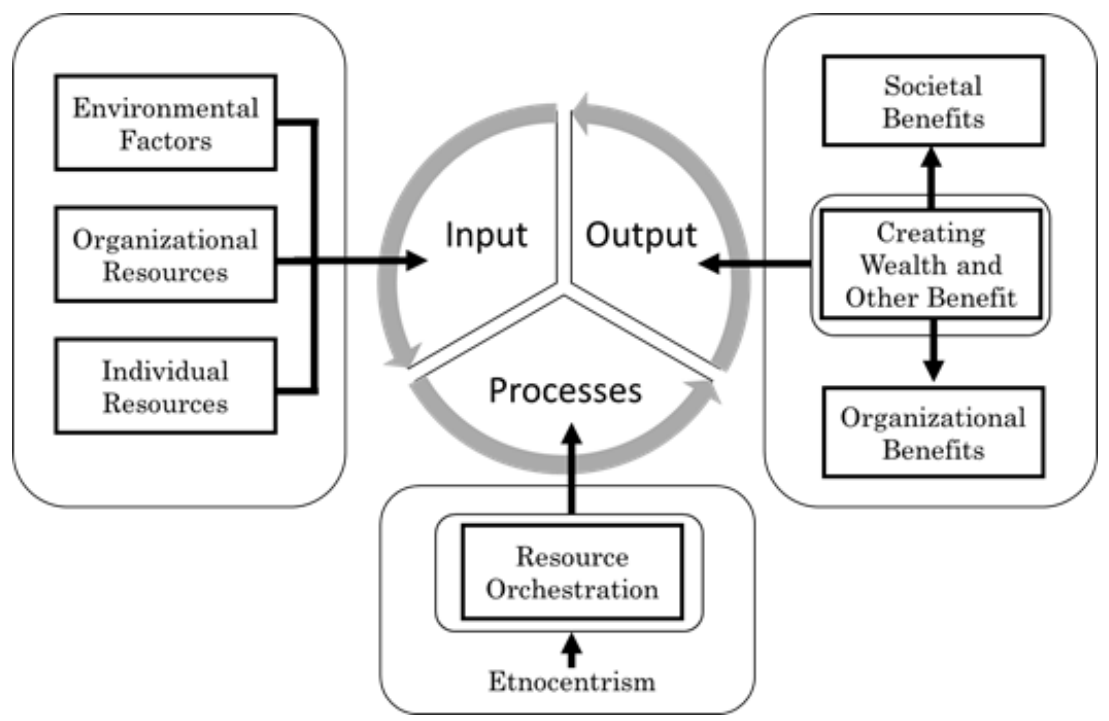

Figure 4: Suggestions for Strategic Entrepreneurship Cooperative Design Models. 
maintain social benefits and organizational benefits more than individual benefits.

The resource orchestra is inseparable from the community's cultural characteristics, which assume that local cultural values are superior to others. By maintaining the quality of the environment, the environment will also maintain the quality of their life. Emphasizing inner values to be more beneficial to the community also raises the opinion that the community will not remain silent for itself as an organization that becomes a circulating concept.

The model proposed in the case study of cooperatives in Indonesia is interesting to further develop. Where the specific characteristic ethnocentrism cannot be explained more deeply. However, the evidence shows that the wealth creation of cooperatives is increasing from year to year against the world economic crisis.

\section{CONCLUSIONS}

This study investigates strategic entrepreneurship in Cooperative form (Pasuruan), and the new culture within its operational range. By investigating the existing information, we identify a distinct system that is rather peculiar-this cooperative uses ethnocentrism as an added variable to orchestrate the existing resource. Ethnocentrism also affects Wealth and Benefit output. The previous model by Hitt (2011) shown Individual benefits as one of the expected results, but individual benefits are eliminated within the new model, while Social and Organizational benefits are emphasized.

Analysis of the development of a strategic entrepreneurship model in this study raises an interesting variable. Future studies are expected to be able to explain organizational culture more thoroughly to explain ethnocentrism.

\section{REFERENCE}

Anheier, H. K., Toepler, S., \& List, R. (2010). International Encyclopedia of Civil Society. In H. K. Anheier \& S. Toepler (Eds.), International Encyclopedia of Civil Society. Springer Science+Business Media, LLC. https://doi.org/10.1007/978-0-387-93996-4

Birchall, J. (1997). International Co-Operative Movement. Manchester University Press.

Corina, J. G. (1994). William King (1786-1865): Physician and Father of the Co-Operative Movement. Journal of Medical Biography, 2(3), 168-176. https://doi.org/10.1177/096777209400200309

Covin, J. G., \& Miles, M. P. (1999). Corporate Entrepreneurship and the Pursuit of Competitive Advantage. Entrepreneurship Theory and Practice. https://doi.org/10.1177/104225879902300304
Creswell, J. (2013). Qualitative, quantitative, and mixed methods approaches. In Research design.

Diaz-Foncea, M., \& Marcuello, C. (2013). Entrepreneurs and the context of cooperative organizations: A definition of cooperative entrepreneur. Canadian Journal of Administrative Sciences. https://doi.org/10.1002/cjas.1267

Hitt, M. A., \& Duane, R. (2002). The Essence of Strategic Leadership: Managing Human and Social Capital. Journal of Leadership \& Organizational Studies. https://doi.org/10.1177/107179190200900101

Hitt, M. A., Ireland, R. D., Camp, S. M., \& Sexton, D. L. (2001). Strategic entrepreneurship: entrepreneurial strategies for wealth creation. Strategic Management Journal. https://doi.org/10.1002/smj.196

Hitt, M., Ireland, R., Sirmon, D., \& Trahms, C. (2011). Strategic entrepreneurship: Creating value for individuals, organizations, and society. Academy of Management Perspectives. https://doi.org/10.5465/AMP.2011.61020802

Ireland, R. D. (2001). Integrating entrepreneurship and strategic management actions to create firm wealth. Academy of Management Executive. https://doi.org/10.5465/AME.2001.4251393

Ireland, R. D., Hitt, M. A., \& Sirmon, D. G. (2003). A model of strategic enterpreneurship: The construct and its dimensions. Journal of Management, 29(6), 963-989. https://doi.org/10.1016/S0149-2063(03)00086-2

Ireland, R. D., \& Webb, J. W. (2009). Crossing the great divide of strategic entrepreneurship: Transitioning between exploration and exploitation. Business Horizons, 52(5), 469-479. https://doi.org/10.1016/j.bushor.2009.05.002

Kauranen, I., Henning Reschke, C., \& Kraus, S. (2007). Identification of domains for a new conceptual model of strategic entrepreneurship using the configuration approach. Management Research Review, 34(1), 58-74. https://doi.org/10.1108/01409171111096478

Kyrgidou, L. P., \& Hughes, M. (2010a). Strategic entrepreneurship : origins, core elements and research directions identify elements that aid SE to successfully unfold, offering an improved model. European Business Review.

Kyrgidou, L. P., \& Hughes, M. (2010b). Strategic entrepreneurship: origins, core elements and research directions. European Business Review, 22(1), 43-63. https://doi.org/10.1108/09555341011009007

Luke, B., Kearins, K., \& Verreynne, M. L. (2011). Developing a conceptual framework of strategic entrepreneurship. International Journal of Entrepreneurial Behaviour and Research. https://doi.org/10.1108/13552551111130736

Lumpkin, G. T., Steier, L., \& Wright, M. (2011). In Family Business Business and Strategic. Strategic Entrepreneurship Journal. https://doi.org/10.1002/sej

MacPherson, I. (2012). Cooperative's concern for the community: from members towards local communities' interest. In Euricse Working Paper (No. 46; 13).

Meyer, J. W., \& Rowan, B. (1977). Institutionalized Organizations: Formal Structure as Myth and Ceremony. American Journal of Sociology. https://doi.org/10.1086/226550

Morici, B. C., \& Zander, I. (2020). Developments in strategic entrepreneurship. Foundations and Trends in Entrepreneurship, 16(6), 444-513. https://doi.org/10.1561/0300000094

Schindehutte, M., \& Morris, M. H. (2009). Advancing strategic entrepreneurship research: The role of complexity science in shifting the paradigm. Entrepreneurship: Theory and Practice. https://doi.org/10.1111/j.1540-6520.2008.00288.x 
The International Co-operative Alliance. (2018). Cooperative identity, Values \& Principle.

Tocher, N., Oswald, S. L., \& Hall, D. J. (2015). Proposing Social Resources as the Fundamental Catalyst Toward Opportunity Creation. Strategic Entrepreneurship Journal. https://doi.org/10.1002/sej.1195

Tremblay, E., Hupper, A., \& Waring, T. M. (2019). Co-operatives exhibit greater behavioral cooperation than comparable businesses: Experimental evidence. Journal of Co-Operative Organization and Management, 7.

https://doi.org/10.1016/j.jcom.2019.100092

Welter, C., Mauer, R., \& Wuebker, R. J. (2016). Bridging Behavioral Models and Theoretical Concepts: Effectuation and Bricolage in the Opportunity Creation Framework. Strategic Entrepreneurship Journal. https://doi.org/10.1002/sej.1215

Received on 28-06-2021 Accepted on 11-08-2021

Published on 13-08-2021

https://doi.org/10.6000/1929-4409.2021.10.149

(C) 2021 Chakim et al.; Licensee Lifescience Global.

This is an open access article licensed under the terms of the Creative Commons Attribution Non-Commercial License (http://creativecommons.org/licenses/by-nc/3.0/) which permits unrestricted, non-commercial use, distribution and reproduction in any medium, provided the work is properly cited. 